\title{
Chemical and Microbial Degradation of Atrazine in Japanese and Thai Soils
}

\author{
Roongnapa Korpraditskul, Arata Katayama and Shozo Kuwatsuka \\ Laboratory of Soil Science, Faculty of Agriculture, Nagoya University, \\ Chikusa-ku, Nagoya 464-01, Japan
}

(Received May 28, 1992; Accepted August 31, 1992)

\begin{abstract}
Effects of soil properties and microorganisms on the degradation of the herbicide atrazine was studied using five Japanese (alluvial and volcanic ash soils) and two Thai soils (alluvial and calcareous soils). Among soil properties, soil $\mathrm{pH}$ showed the highest positive correlation to the half-life of atrazine in the soils $(r=0.79)$. Differences in the atrazine degradation rates in the soils at the same $\mathrm{pH}$ suggested that effects of other soil properties were also involved. Comparison of the atrazine degradation rates in sterilized (autoclaved) and nonsterilized soils indicated that the contribution of chemical degradation to atrazine degradation was more than $80 \%$ in a $\mathrm{pH}$ range of 4 to 8 . The long-term application of atrazine did not increase the degradation rates. Although the contribution of microbial degradation was less than $20 \%$ and distinct only after 20 days of incubation, the population of atrazine degraders was $10^{5}-10^{6}$ cells/g soil even in soils virgin to atrazine. This suggested that the microbial degradation of atrazine was mainly determined not by the population of atrazine degraders, but by soil conditions they work under.
\end{abstract}

\section{INTRODUCTION}

The herbicide atrazine (2-chloro-4-ethylamino-6-isopropylamino-1,3,5-triazine) has been widely used for weed control in sugarcane, corn and other crop fields. Recently, it was found that the drinking water is contaminated with atrazine to above the upper limit concentration in wide areas. ${ }^{1)}$ Numerous studies have been conducted on the fate and behaviors of the herbicide in soils. ${ }^{2,3)}$ They were, however, mainly confined to soils in the temperate zone. Considering the wide usage of atrazine in both temperate and tropical agricultural fields, it is of importance to study the fate and behavior of atrazine in soils in the tropical zone too. In our previous paper, we reported that atrazine rapidly degraded in tropical soils (Thai soils), and that high temperatures accelerated the degradation. ${ }^{4)} \mathrm{Up}$ to now, however, the behavior of atrazine in volcanic ash soils of the temperate zone has not been documented well in spite of the wide distribution of volcanic ash soil in Japan.

In this study, using temperate (Japanese) and tropical (Thai) soils, a comparative study was carried out to determine soil properties affecting the degradation of atrazine in soil. The effect of soil $\mathrm{pH}$ was also studied in both temperate and tropical soils since it was reported to affect atrazine degradation greatly in temperate soils. ${ }^{5)}$ Contributions of microbial and chemical actions to atrazine degradation in soils were evaluated under various conditions in addition to the enumeration of atrazine-degrading microorganisms in soils.

\section{MATERIALS AND METHODS}

\section{Chemicals}

All solvents were analytical grade. The reference standard chemicals of atrazine (99.8 or $98.0 \%$ ) were obtained from CIBA-GEIGY (Japan) Limited. 


\section{Soils}

Five soil samples from Japan and two from Thailand were used in the degradation study (Table 1). Fukaya soil and two Ushiku soils were volcanic ash type, and Anjo and Nagano soils were alluvial mineral type. One Ushiku (LT) soil had been applied with atrazine for the past nine years, and Ta Kli soil was collected from a sugarcane field where atrazine had been regularly applied. The other five soils including the other Ushiku (virgin) had never been exposed to atrazine. The fresh soil samples were crushed to pass through a 2-mm sieve and stored at $4^{\circ} \mathrm{C}$ until use. Some properties of the soils are shown in Table 1.

\section{Atrazine Degradation in Soils}

Soil equivalent to $25 \mathrm{~g}$ on a dry-weight basis was taken into a $100-\mathrm{ml}$ beaker, and the moisture content was adjusted to $50 \%$ of the maximum water-holding capacity (MWHC). After one week of preincubation at $30^{\circ} \mathrm{C}$, atrazine was amended as $250 \mu \mathrm{l}$ of $30 \%$ aqueous acetone solution to make $3 \mathrm{mg} / \mathrm{kg}$ soil of the initial concentration. The atrazine solution was carefully dispersed to the soil surface in the beaker, which was then covered with aluminum foil. The atrazine-amended soils were incubated at $30^{\circ} \mathrm{C}$ in the dark. The moisture content was maintained by adding distilled water once a week. Atrazine degradation in soils sterilized by autoclaving $\left(121^{\circ} \mathrm{C}\right.$ for $30 \mathrm{~min}$, twice in consecutive days) was examined in the same manner. The autoclaving did not affect the soil $\mathrm{pH}$. The $\mathrm{pH}$ values of the Anjo and Ta Kli soils were adjusted by $\mathrm{HCl}$ or $\mathrm{Ca}(\mathrm{OH})_{2}$ in order to study the effect of soil $\mathrm{pH}$ on atrazine degradation. The $\mathrm{pH}$ of the soils was checked and readjusted every 10 days to reach the equilibrium throughout the 50 days' preincubation period.

\section{Atrazine Extraction}

A whole soil sample ( $25 \mathrm{~g}$ on a dry-weight basis) was extracted twice with $100 \mathrm{ml}$ acetone with a mechanical shaker. The extracts were combined and concentrated with a vacuum evaporator. The concentrated sample was partitioned twice with diethyl ether in a separatory funnel. The combined ether solution was dried over anhydrous $\mathrm{Na}_{2} \mathrm{SO}_{4}$ and evaporated to dryness. The residues were dissolved with $n$-hexane and cleaned up through a florisil Sep-pak ${ }^{\circledR}$ cartridge. The eluting solvent was $n$-hexane: ethyl acetate $(7: 3)$. The eluent was subjected to gas chromatographic analysis (GC). The recoveries of atrazine from the Fukaya, Pak Chong, Ta Kli, Anjo, Ushiku (LT), Ushiku and Nagano soils were $94,90,94,88,91,90$ and $90 \%$, respectively.

The residual soils after the acetone extraction were further extracted with $0.1 \mathrm{M} \mathrm{Na}_{4} \mathrm{P}_{2} \mathrm{O}_{7}$ under neutral conditions. ${ }^{6}$. The extractable fractions (humic and fulvic acid) were partitioned with diethyl ether, and the residual soil (humin fraction) was extracted with acetone again as described above to determine the amount of atrazine by GC.

\section{Analysis of Atrazine}

Atrazine was determined with a gas chromatograph (Hewlett Packard HP 5890 series II) equipped with a Nitrogen/Phosphorus

Table 1 Physico-chemical properties of soils used (on a dry weight basis).

\begin{tabular}{|c|c|c|c|c|c|c|c|c|c|}
\hline \multirow{2}{*}{ Soil } & \multirow{2}{*}{ Taxonomy } & \multicolumn{2}{|c|}{$\mathrm{pH}$} & \multirow{2}{*}{$\begin{array}{c}\text { MWHC } \\
(\%)\end{array}$} & \multirow{2}{*}{$\begin{array}{c}\text { Org.C } \\
(\%)\end{array}$} & \multirow{2}{*}{$\begin{array}{c}\text { Total-N } \\
(\%)\end{array}$} & \multirow{2}{*}{$\begin{array}{l}\text { CEC } \\
\text { (meq) }\end{array}$} & \multirow{2}{*}{$\begin{array}{l}\text { Clay } \\
(\%)\end{array}$} & \multirow{2}{*}{$\begin{array}{l}\text { Main clay } \\
\text { minerals }\end{array}$} \\
\hline & & $\mathrm{KCl}$ & $\mathrm{H}_{2} \mathrm{O}$ & & & & & & \\
\hline Fukaya $^{a}$ ) & Dystrandept & 6.1 & 6.5 & 74.8 & 3.26 & 0.26 & 24.74 & 6.8 & Allophane \\
\hline Anjoa) & Dystrochrept & 6.1 & 6.8 & 50.0 & 1.01 & 0.10 & 12.37 & 26.0 & Kaoline \\
\hline Ushiku $(\mathrm{LT})^{\mathrm{a}}{ }^{\mathrm{a}}$ & Dystrandept & 5.7 & 6.3 & 132.7 & 4.97 & 0.37 & 28.19 & 14.9 & Allophane \\
\hline Ushiku $^{\text {a) }}$ & Dystrandept & 5.6 & 6.3 & 115.5 & 5.30 & 0.39 & 30.25 & 14.9 & Allophane \\
\hline Nagano $^{a}$ ) & Haplaquept & 4.9 & 6.1 & 71.2 & 1.40 & 0.14 & 20.09 & 34.8 & Montmorillonite \\
\hline Pak Chong ${ }^{b}$ & Paleustalf & 4.3 & 5.2 & 71.9 & 1.40 & 0.10 & 12.87 & 90.9 & Kaoline \\
\hline Ta Kli $\left.{ }^{b}\right)$ & Rendoll & 7.1 & 7.6 & 84.5 & 2.62 & 1.18 & 21.00 & 53.2 & Smectite \\
\hline
\end{tabular}

\footnotetext{
a) Japanese soil. b) Thai soil.
} 
detector. The column used was DB-1701 (15 $\mathrm{m} \times 0.53 \mathrm{~mm}$ i.d., J \& W Calif., U.S.A.). Injection was done in a splitless mode. The flow rate of carrier gas $\mathrm{He}$ was $12 \mathrm{ml} / \mathrm{min}$. The flow rates of make-up gas $\mathrm{He}, \mathrm{H}_{2}$ and air were 18,30 and $100 \mathrm{ml} / \mathrm{min}$, respectively. The temperatures of the oyen, detector and injection port were 180,250 and $220^{\circ} \mathrm{C}$, respectively. Under these conditions, the retention time of atrazine was $4.6 \mathrm{~min}$.

\section{Enumeration of Atrazine Degraders}

The populations of atrazine-degrading microorganisms in the Anjo and Pak Chong soils were enumerated by the most probable number (MPN) method. ${ }^{7)}$ The culture medium was tenfold diluted nutrient broth containing $3 \mathrm{mg} / l$ of atrazine. The soil suspension of the two soils was diluted serially after shaking mechanically for $15 \mathrm{~min}$. After transferring $1 \mathrm{ml}$ of the suspension to $9 \mathrm{ml}$ of the culture medium in a test tube, the suspension was incubated without agitation at $30^{\circ} \mathrm{C}$.

After 30 days of incubation, $2 \mathrm{ml}$ of the culture medium was transferred to a screwcapped tube, mixed with $3 \mathrm{ml}$ of $10 \% \mathrm{NaCl}$ and extracted with $3 \mathrm{ml}$ of diethyl ether by shaking mechanically for $30 \mathrm{~min}$. The extracted atrazine was directly analyzed by GC. A culture medium inoculated with autoclaved soil suspension served as control. The positive reaction was determined by the loss of atrazine in the tube by more than $20 \%$ compared to the control tubes. Five MPN tubes were provided for each set of dilution.

\section{RESULTS AND DISCUSSION}

The degradation rates of atrazine in the soils were determined by the acetone extraction method. The relative rates of atrazine degradation in the soils are shown in Fig. 1. The degradation of atrazine in the soils appeared to follow the first order kinetics. Their half-lives estimated were in a range of 20 to 150 days in the following order: 150 (Ta Kli) $>$ 47 (Ushiku virgin) $>39$ (Ushiku LT, applied with atrazine for nine years) $>34$ (Anjo) $>27$ (Fukaya) $>22$ (Nagano) $>20$ days(Pak Chong). Among the soil properties examined (in Table 1), the half-life of atrazine in the soils was significantly correlated with $\mathrm{pH}(\mathrm{KCl})$

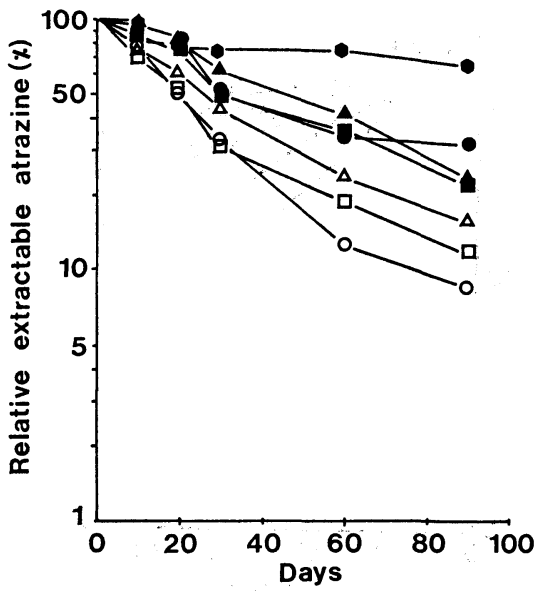

Fig. 1 Degradation of herbicide atrazine in different soils.

$\circ$ : Pak Chong, $\triangle$ : Fukaya, $\square$ : Nagano, $\bullet$ : Anjo,

$\Delta$ : Ushiku (virgin), $\mathbf{\square}$ : Ushiku (LT), : Ta Kli.

The difference of duplicate values was less than $5.2 \%$ based on the initial values.

(correlation coefficient, $r=0.76)$ and $\mathrm{pH}\left(\mathrm{H}_{2} \mathrm{O}\right)$ $(r=0.79)$, but not with MWHC $(r=0.12)$, organic carbon $(r=0.11)$, CEC $(r=0.11)$ and clay content $(r=0.15)$. In this comparative study, used were tropical and temperate soils, alluvial and volcanic ash soils, long-term atrazine-treated soils and virgin soils. In them, soil $\mathrm{pH}$ was a significant factor correlating with the half-life of atrazine, which indicated that soil $\mathrm{pH}$ played an important role in atrazine degradation in the soils.

To distinguish microbial degradation from chemical degradation, degradation of atrazine was examined under sterilized and nonsterilized conditions using three soil samples, Ushiku LT and virgin and Pak Chong soils (Fig. 2). The atrazine concentration in the Pak Chong soil decreased more rapidly than in both Ushiku soils under both sterilized and nonsterilized conditions, due to acidic conditions as described above. From the results with sterilized soils, it was evident that atrazine dissipated continuously through chemical degradation throughout the incubation period. Microbial degradation, which was estimated from the difference in the residual amounts of atrazine in sterilized and nonsterilized soils, apparently started after 20 days of incubation. 


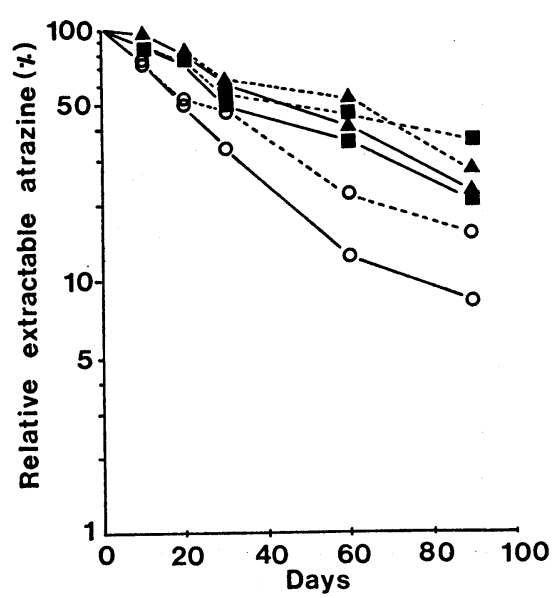

Fig. 2 Degradation of herbicide atrazine in soils under sterilized and non-sterilized condition.

......: sterilized soil, — : non-sterilized soil, $\bigcirc$ : Pak Chong, $\mathbf{\Delta}$ : Ushiku (virgin), $\mathbf{\square}$ : Ushiku (LT), The difference of duplicate values was less than $6.1 \%$ based on the initial values.

The contributions of chemical and microbial degradations to the total degradation after 90 days of incubation were $92.8 \%$ and $7.2 \%$ in the Pak Chong soil, $80.4 \%$ and $19.6 \%$ in the Ushiku LT soil, and $94.0 \%$ and $6.0 \%$ in the Ushiku virgin soil, respectively. The results clearly showed that the contribution of biological activity to atrazine degradation was smaller than chemical activity in all the soils investigated.

There was no significant difference in the atrazine degradation rates in the Ushiku LT and Ushiku virgin soils. This suggests that long-term application did not affect the degradation rate in the Ushiku soils. Although there was a little increase in the microbial contribution to the total degradation in the Ushiku LT soil, its half-life was not significantly different from that in the Ushiku virgin soil.

The effect of soil $\mathrm{pH}$ on the degradation of atrazine in Ta Kli and Anjo soils was studied under both sterilized and nonsterilized conditions, as shown in Fig. 3. Although biological degradation was observed at all $\mathrm{pH}$ levels $(\mathrm{pH}=4,7$ and 8$)$, chemical degradation was the main process in the atrazine degradation at all $\mathrm{pH}$ levels, especially at $\mathrm{pH} 4$. The contribution of biological degradation to the total

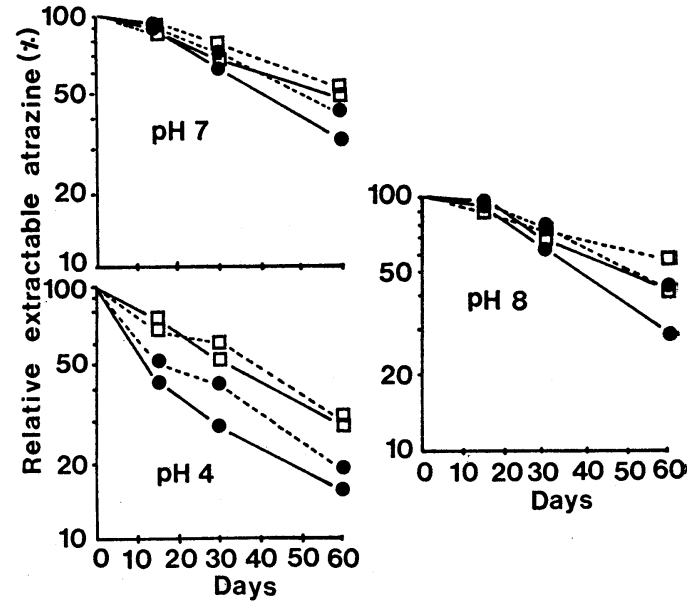

Fig. 3 Degradation of herbicide atrazine in Anjo and $\mathrm{Ta} \mathrm{Kli}$ soils at various $\mathrm{pH}$ conditions.

......: sterilized soil, __ Anjo, $\square:$ Ta Kli.

The difference of duplicate values was less than $5.2 \%$ based on the initial values.

degradation after 30 days of incubation in the Anjo and Ta Kli soils were 3.5 and 6.9, 13.4 and $7.7,8.1$ and $20.0 \%$ at $\mathrm{pH} 4,7$ and 8 , respectively. Figure 4 shows the effect of soil $\mathrm{pH}$ on the half-life of atrazine in soils adjusted to different $\mathrm{pH}$ levels. The contribution of biological degradation was higher at $\mathrm{pH} 8$ in the Ta Kli soil, whereas at $\mathrm{pH} 6$ and 8 it was higher in the Anjo soil. The contribution of chemical degradation was higher in both soils under acidic soil conditions. It has been reported that chemical hydrolysis of atrazine occurs in aqueous solution when $\mathrm{pH}$ departs from neutral, and that an addition of soil or clay minerals to the aqueous solution enhances the chemical hydrolysis. ${ }^{5,8,9}$. This study found that chemical degradation primarily occurred in soils and that the half-life of atrazine was shorter in soils with lower (acidic) pH. These results are in good agreement with those of studies on chemical hydrolysis of atrazine in solution. ${ }^{5,9)}$

The half-life of atrazine at $\mathrm{pH} 4$ was 3.5 and 4.5 times shorter than that at $\mathrm{pH} 8$ in nonsterilized and sterilized Anjo soils, respectively. This difference in the half-lives at $\mathrm{pH} 4$ and 8 seemed to be too large, probably because atrazine is nonextractable in soil at 


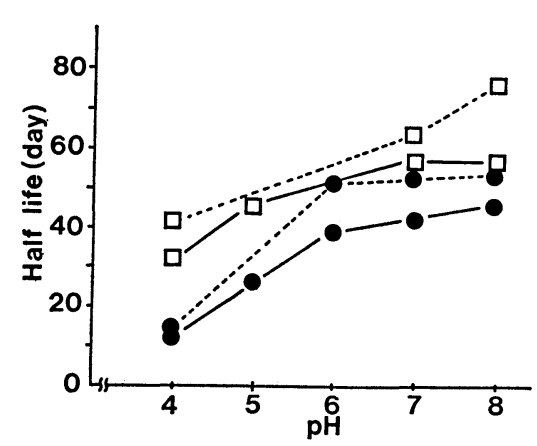

Fig. 4 Half-lives of herbicide atrazine in Anjo and Ta Kli soils at various $\mathrm{pH}$ conditions.

......: sterilized soil, _ Anjo, $\square$ : Ta Kli.

The difference of duplicate values was less than $4.2 \%$

under lower $\mathrm{pH}$ levels. Recent studies ${ }^{10-12)}$ have claimed the possibility of underestimation of atrazine residue by conventional extraction procedures because of incomplete extraction. In case the extraction with acetone in this study was insufficient, chemical degradation may be difficult to distinguish in a "bound residue" form. A supplementary experiment was therefore conducted to extract atrazine in a "bound residue" form from the soils. Autoclaved soil samples (pH 5 and 8) after acetone extraction were further extracted by the conventional extraction method with a humic substance $\left(0.1 \mathrm{~m} \mathrm{Na} \mathrm{Na}_{2} \mathrm{O}_{7} ; \mathrm{pH}\right.$ 7). The amounts of atrazine in the extracted fraction and the residual soil were analyzed. As shown in Table 2, the amounts of atrazine detected in the $\mathrm{Na}_{2} \mathrm{P}_{2} \mathrm{O}_{7}$-extractable fraction and in the residual soil were not largely different between two Anjo soils adjusted at $\mathrm{pH}$ 5 and 8 , and much smaller than those extracted with acetone first. The summations of the amounts of atrazine were remarkably smaller in the soil adjusted to $\mathrm{pH} 5$ than in the one adjusted to $\mathrm{pH} 8$. This indicated that the results obtained from the first acetone extraction were reliable. This additional experiment also confirmed our conclusion that chemical degradation of atrazine occurs more rapidly in soils at lower $\mathrm{pH}$ levels.

The degradation of atrazine in soil seems to depend mainly on soil $\mathrm{pH}$, since other soil
Table 2 Percentage of atrazine recovered from autoclaved Anjo soils adjusted at different $\mathrm{pH}$ after 30 days of incubation by using a successive extraction method.

\begin{tabular}{ccccc}
\hline & \multirow{3}{*}{$\begin{array}{c}\text { First } \\
\text { acetone } \\
\text { extract }\end{array}$} & \multicolumn{2}{c}{$\begin{array}{c}\text { Residual soil treated } \\
\text { with } \mathrm{Na}_{4} \mathrm{P}_{2} \mathrm{O}_{7}\end{array}$} & \\
\cline { 3 - 4 } & $\begin{array}{c}\text { Soluble } \\
\text { fraction }\end{array}$ & $\begin{array}{c}\text { Soil } \\
\text { residues }\end{array}$ & $\begin{array}{c}\text { Summa- } \\
\text { tion }\end{array}$ \\
\hline 5 & 50.7 & 4.0 & 0.7 & 55.4 \\
8 & 75.6 & 5.4 & 1.2 & 82.2 \\
\hline
\end{tabular}

properties showed relatively minor correlation to the half-life of atrazine and the contribution of microbial degradation was small in our study, as mentioned above. However, the different half-lives of atrazine in sterilized Anjo and $\mathrm{Ta} \mathrm{Kli}$ soils at the same soil $\mathrm{pH}$ level as seen in Fig. 4 indicated that some other soil properties also affected the chemical degradation rate. The half-lives in the Ta Kli soil were 3.2, 1.2 and 1.5 times longer than in the Anjo soil at $\mathrm{pH} \mathrm{4,7}$ and 8, respectively. Two major differences in the physicochemical properties of the Anjo and Ta Kli soils are the type of main clay minerals and organic matter content (Table 1). Atrazine degradation occurred more favorably in the kaolinite-type of Anjo clay soil than in the smectite-type Ta Kli clay soil at all the $\mathrm{pH}$ levels examined. The organic matter content of the Ta Kli soil was higher than that of the Anjo soil. Both organic matter and 2: 1 clay mineral have been reported to adsorb atrazine strongly, causing long persistence of atrazine in soil at neutral $\mathrm{pH}$ levels, while at acidic levels the adsorption appears to accelerate the hydrolysis of chloro-s-triazine compounds. ${ }^{18-18)}$ The atrazine degradation rates increased as atrazine adsorption to soils increased. ${ }^{9)}$ It is likely that the high organic matter content and the 2: 1 clay type of calcareous $\mathrm{Ta} \mathrm{Kli}$ soils resulted in the longer persistence of atrazine than in the Anjo soil in the range of $\mathrm{pH} 6$ to 8. In three volcanic ash soils, Fukaya, Ushiku LT and Ushiku virgin, with similar $\mathrm{pH}$ values, the half-lives of atrazine were longer in the soils that contain organic matter in larger amounts. These results also show that the sorption of atrazine to soil organic matter 
retards degradation at neutral $\mathrm{pH}$ levels. The soil organic matter content and the type of clay minerals other than soil $\mathrm{pH}$ affected integratedly the chemical hydrolysis of atrazine in the soils we used.

At $\mathrm{pH} \mathrm{4,} \mathrm{the} \mathrm{difference} \mathrm{in} \mathrm{the} \mathrm{half-lives} \mathrm{in}$ Anjo and Ta Kli soils were larger than at higher $\mathrm{pH}$ levels (Fig. 4). This indicates that acidic condition promoted atrazine degradation in the Anjo soil. These results did not accord with the finding that the hydrolysis reaction of atrazine was accelerated by stronger adsorption to soil under highly acidic conditions, indicating that $\mathrm{Ta} \mathrm{Kli}$ soil has some properties to retard atrazine degradation. Although the causal soil properties to explain this discrepancy could not be identified from the current data, it should be noted that Ta $\mathrm{Kli}$ soil is a calcareous soil with high $\mathrm{pH}$ by nature. Notwithstanding the adjustment to $\mathrm{pH} 4$ every 10 days, the $\mathrm{pH}$ of the Ta Kli soil still slightly increased during the 50 days of preincubation. In contrast, the $\mathrm{pH}$ of the Anjo soil showed a slight change only during the first 10 days and became stable afterwards. It could be deduced that the Ta Kli soil adjusted to $\mathrm{pH} 4$ might have been incubated at higher $\mathrm{pH}$ than intended during the incubation, and that the higher $\mathrm{pH}$ resulted in the longer halflife than expected. It is noteworthy from the viewpoint of atrazine persistence in soil that atrazine was degraded very slowly in the calcareous Ta Kli soil, the type of which is widely distributed in Thailand.

Although the contribution of microbial degradation was smaller than that of chemical degradation at all $\mathrm{pH}$ levels examined, it appears that microbial degradation increased as soil $\mathrm{pH}$ increased. Biological degradation was observed even in virgin soils such as Ushiku virgin, Pak Chong and Anjo (Figs. 2 and 3). It is essential to investigate microbial activities to degrade atrazine in soils of both temperate and tropical zones.

Several researchers have reported on the degradation of atrazine by isolated soil bacteria, fungi and actinomycetes. ${ }^{2,19,20)}$ It should be noticed that atrazine is present in ground water although chemical and biological degradation readily occur in soi: There has been no report on the relationship between the degradation rate of atrazine and the population of its degraders in soil. In this experiment, the Anjo soil harbored $2.1 \times 10^{6}$ cells $/ g$ soil of atrazine degraders and the Pak Chong soil $4.5 \times 10^{5}$. Such numbers of microorganisms were present even in the virgin soils to degrade atrazine. In spite of such a high population of degraders, the contribution of microbial reaction to atrazine degradation in the soils was fairly small, and the high population did not make the half-life of atrazine any shorter. This indicates that atrazine degradation in the soils was determined not by the population of atrazine degraders, but mainly by the soil conditions they work under.

The present study demonstrates the contributions of chemical and microbial degradation to atrazine dissipation in soil. The contribution of chemical degradation was larger than that of microbial degradation, although the contribution changed according to $\mathrm{pH}$ levels. Although the contribution of microbial degradation of atrazine was relatively small in this study, atrazine degraders were present at high levels both in Japanese and Thai soils. This result indicates a potential that atrazine transforms itself in the soil ecosystem and contaminates ground water. Further studies are necessary to elucidate the mechanisms of degrading activities of microorganisms in soil. It is also important to study metabolites produced through biological and chemical degradations probably different under various soil conditions.

\section{ACKNOWLEDGMENTS}

The authors wish to express their deep gratitude to Dr. M. Kimura, the Professor of this laboratory, for his invaluable advice and critical concerns with this manuscript. Thanks are also due to Dr. A. Watanabe for his kind assistance on humic substance extraction as well as for his helpful advice.

\section{REFERENCES}

1) C. Wittman \& B. Hock: J. Agric. Food Chem. 39, 1194 (1991)

2) D. D. Kaufman \& P. C. Kearney: Res. Rev. 32, 235 (1970)

3) L. S. Jordan, W. J. Farmer, J. R. Goodin \& B. E. Day: Res. Rev. 32, 267 (1970)

4) R. Korpraditskul, V. Korpraditskul \& S. Kuwa- 
tsuka: J. Pesticide Sci. 17, 287 (1992)

5) J. B. Weber \& S. B. Weed: "Pesticides in Soil and Water," ed. by W. D. Guenzi, J. L. Ahlrichs, G. Chesters, M. E. Bloodworth \& R. G. Nash, Soil Science Society of America, Inc., Publisher, Madison, WI, pp. 223-256, 1974

6) K. Kumada \& S. Ota: J. Sci. Soil Manure, Jpn. 34, 423 (1963) (in Japanese)

7) W. G. Cochran: Biometrics 5, 105 (1950)

8) T. W. Jones, W. M. Kemp, J. C. Stevensen \& J. C. Means: J. Environ. Qual. 11, 632 (1982)

9) D. E. Armstrong, G. Chesters \& R. F. Harris: Soil Sci. Soc. Am. Proc. 31, 61 (1967)

10) D. A. Winkelmann \& S. J. Klaine: "Pesticide Transformation Products," ed. by L. Somsundaram \& J. R. Coats, ACS Symposium Series 459, pp. 75-92, 1991

11) M. Schiavon: Ecotoxicol. Environ. Saf. 15, 46 (1988)

12) M. Schiavon: Ecotoxicol. Environ. Saf. 15, 55 (1988)

13) R. P. Upchurch \& D. D. Mason: Weeds 10, 9 (1962)

14) T. J. Sheets, A. S. Crafts \& H. R. Drever: $J$. Agric. Food Chem. 10, 458 (1962)

15) J. D. Russel, M. Cruz, J. L. White, G. W. Baily, W. R. Payne, Jr., J. D. Pope, Jr. \& J. J. Teasly: Science 160, 1340 (1968)

16) J. L. White: Arch. Environ. Contam. Toxicol. 3, 461 (1975)

17) J. B. Weber \& S. B. Weed: Soil Sci. Soc. Am. Proc. 32, 485 (1968)

18) M. J. Frissel \& G. H. Bolt: Soil Sci. 94, 284 (1962)
19) A. M. Cook \& R. Hutter: J. Agric. Food Chem. 29, 1135 (1981)

20) M. C. Giardina, M. T. Giardi \& G. Filacchioni: Agric. Biol. Chem. 46, 1439 (1982)

\section{要 約}

\section{日本およびタイの土壤中におけるアトラジンの 化学的. 微生物的分解}

Roongnapa KORPRADITSKUL 片山新太，鉦塚昭三

除草剂アトラジンの分解速度におよぼす土㙋の性質と 微生物の影響を日本の土歵 5 種とタイの土壌 2 種を用い て研究した.土壌の性質のうち, 土壌 $\mathrm{pH}$ がアトラジン の半減期に最も大きく影響した（相関係数 0.79）。また， 同じ $\mathrm{pH}$ に調整した土塞中でのアトラジンの分解速度の 違いから他の土堙の性質も影響することが示唆された.

オートクレーブ殺菌した土壌と非殺菌土壌中におけるア トラジンの分解速度の比較により, $\mathrm{pH} 4 \sim 8$ では土镶 中でのアトラジンの分解の $80 \%$ 以上が化学的分解によ るものであることが示された. アトラジンの長期連用に よる分解速度の増加は認められなかった. 微生物分解 は，土裹中におけるアトラジン分解の $20 \%$ 以下の寄与 しかなく，またアトラジンを土堙に添加後 20 日以降に のみにしか認められないが，アトラジン分解菌はアトラ ジンを過去施用したことのない土壤中でる $10^{5} \sim 10^{6}$ 個/ $\mathrm{g}$ 土裹以上存在した.アトラジンの土堙中における微生 物分解は，その菌数によって決まるのではなく菌を取り 巻く土鲂条件によることが示唆された。 